\title{
The Circulation of Ptolemaic Silver in Seleucid Coele Syria and Phoenicia from Antiochus ili to the Maccabean Revolt: Monetary Policies and Political Consequences
}

\author{
Catharine Lorber
}

\begin{abstract}
This paper examines the circulation of Ptolemaic silver in the closed monetary zone of Seleucid Coele Syria and Phoenicia. No new silver coinage entered the zone under Antiochus III and Seleucus IV, though hoards were deposited in the Transjordan and eastern Judah in the early years of Antiochus IV. Trade between Phoenicia and Egypt is excluded as an explanatory factor, but the patterns are consistent with Josephus' account of the dowry of Cleopatra I and Tobiad tax farming. In the 160s BCE fresh Ptolemaic silver began to enter the closed monetary zone, with the earliest finds in Judah, Samaria, and "southern Palestine." This new influx, like the didrachms "of an uncertain era," may represent a subsidy from Ptolemy VI to the Maccabees and other dissidents from Seleucid rule.
\end{abstract}

Keywords: closed monetary zone, Ptolemaic silver coinage, dowry, Tobiad, tax farming, Judah, Antiochus III, Antiochus IV, Ptolemy V, Ptolemy VI.

When Antiochus III seized Phoenicia and Palestine from Ptolemy V, the region comprised a closed monetary zone in which Ptolemaic coinage was the sole legal tender. Somewhat surprisingly, Antiochus III maintained the closed monetary zone for precious metal coinage, which in practice meant silver coinage. This curious situation was defined by Georges Le Rider in 1995 through the study of coin hoards. ${ }^{1}$ The hoards reveal that for nearly half a century the only silver coinage circulating in Seleucid Coele Syria and Phoenicia was Ptolemaic. Seleucid silver coinage was excluded from the province, apparently because it adhered to the heavier Attic weight standard. Even Attic-weight coinage struck at the coastal mints beginning in the reign of Seleucus IV did not circulate locally.

While Antiochus III adopted a laissez-faire policy with respect to Ptolemaic silver, he promptly began to strike bronze coinage at the mint of Tyre, bearing his portrait on the 
obverse and using reverse types of local significance. ${ }^{2}$ Seleucid bronze coinage was also issued at Ptolemais-Akko. ${ }^{3}$

This peculiar state of affairs-Seleucid coinage restricted to bronze and a monopoly for Ptolemaic silver - raises questions about the motives behind the monetary policy. Was Antiochus III indifferent to the dynastic symbolism of the Ptolemaic silver and to the superior prestige implied for the Ptolemies by the hierarchy of monetary metals and coin values? Le Rider conceded a sacrifice of prestige but considered the policy of Antiochus III to fall within Seleucid tradition, because the Seleucids, since Seleucus I, had always tolerated the circulation of earlier coinage in their realm. ${ }^{4}$ Le Rider suggested that the closed monetary zone was maintained to preserve trade with Egypt and to protect the prosperity of the inhabitants of Coele Syria and Phoenicia, and he further noted the profits to be gained from enforced monetary exchange at the points of entry. ${ }^{5}$ Arthur Houghton and Catharine Lorber envisioned fiscal constraints that militated against integrating Coele Syria and Phoenicia into the broader economy of the Seleucid empire, specifically the expense of replacing the Ptolemaic silver with heavier Attic-weight silver. ${ }^{6}$ Dan Barag, echoing an opinion of Henri Seyrig, thought the continued use of Ptolemaic silver coinage reflected a rejection of Attic-weight coinage by the local population, while Seyrig added that the decisive factor was commercial ties between Alexandria and the cities of Phoenicia. ${ }^{7}$ None of these authors considered the alternative of quickly replacing the Ptolemaic silver with a new Seleucid coinage on a compatible weight standard, or the even simpler alternative of countermarking the Ptolemaic silver with some symbol of Seleucid authority, so as to reauthorize it as an official Seleucid currency. ${ }^{8}$ And this despite the fact that Le Rider had elsewhere emphasized the profit accruing to the state from countermarking. 9

The anomalies of the closed monetary zone also raise questions about fiscal practicalities. Did the provincial administration of Antiochus III compensate soldiers and other state employees with Ptolemaic currency, or with Attic-weight Seleucid silver that could not be spent locally? Or did the administration attempt to emulate contemporary Lagid fiscal policy in Egypt, which relied on bronze coinage and payments kind to the nearly complete exclusion of silver?

The ambiguity of the coinage with respect to Seleucid sovereignty was reinforced by and probably related to the unusual fiscal status of Coele Syria and Phoenicia under Antiochus III and his sons. ${ }^{10}$ In Book 12 of his Jewish Antiquities Josephus reports that

2 Houghton-Lorber 2002, nos. 1078-1083.

3 Houghton - Lorber 2002, no. 1096.

4 Le Rider 1995, 402-403.

5 Le Rider 1995, 402-403, followed by Duyrat (2016, 364-365), who considered the avoidance of disruption the more compelling motive.

6 Houghton - Lorber 2002, 54-56.

7 Seyrig 1973, 121; Barag 2007/2008, 29.

8 On Seleucid countermarking of foreign silver coins in the second century, see Houghton - Lorber Hoover 2008, II: 157-165. On countermarking generally: Le Rider 1975.

9 Le Rider 1975, 43.

10 This suggestion was made earlier by Schwartz $(1998,60)$, though his description of the closed monetary zone was not entirely accurate with respect to the coexistence of the Attic and Ptolemaic standards. The suggestion was repeated by Sartre (2014, 11-12), again with a numismatic error: the Cypriote silver coins he cited as circulating in the original Lagid province were in fact struck in the reign of Ptolemy VI. 
Phoenicia, Coele Syria, Samaria, and Judah were returned to Ptolemy V at the end of the Fifth Syrian War, when he allied with Antiochus III. ${ }^{11}$ According to Josephus, these territories constituted the dowry of Antiochus' daughter Cleopatra, who was given in marriage to Ptolemy to seal the alliance. ${ }^{12}$ Josephus promptly makes clear that the dowry was not a return of territory, but of designated tax revenues. Nevertheless, many historians have been skeptical of the claim that Coele Syria and Phoenicia, or even their revenues, were returned to Ptolemy V. ${ }^{13}$ A related difficulty is that the information about Cleopatra's dowry is linked to a novelistic account of Tobiad family history which is riddled with chronological inconsistencies ${ }^{14}$ Accordingly, most historians have either rejected or reinterpreted the relevant passages. For the purposes of this investigation, let us assume that Josephus provides accurate information about the dowry and that his Tales of the Tobiads are generally reliable insofar as they relate to tax farming. ${ }^{15}$

Initially, apparently from the alliance in $195 \mathrm{BCE}$ until the wedding in winter of 194/193 BCE, the taxes on these territories were divided equally between the two kings, and the division was made at the local level. ${ }^{16}$ Josephus' account inserts a clearly anachronistic reference to troubles between the Samarians and the Judahites and an apparently anachronistic episode involving the greedy high priest Onias and a King Ptolemy which results in an embassy by Onias' nephew, Joseph son of Tobias, to Ptolemy V and Cleopatra I in Egypt. ${ }^{17}$ In some manuscripts the King Ptolemy who was angered by Onias is identified as "Euergetes, who was the father of Philopator," and this has led many scholars to reject a second-century date for the embassy of Joseph son of Tobias, and in some cases also for the ensuing events. ${ }^{18}$ But Josephus' description of the embassy is persuasive, despite the heroization of its protagonist, because it reveals some knowledge of how tax farming contracts were let in Ptolemaic Egypt. ${ }^{19}$ The visit of Joseph son of Tobias coincides with the first annual auction for farming the taxes of the cities of Coele Syria and Phoenicia. ${ }^{20}$ Having become an intimate of the king and queen, Joseph son of Tobias doubles the combined bids of his competitors from the Syro-Phoenician cities, is awarded the contract for the entire province, and is even excused from the normal requirement for

11 Jos. $A J 12.154$.

12 The dowry is also attested by App. Syr. 5 and Por. FGrH 260 F 47 (ap. Hieron. In Dan. 11.17).

13 See, e.g., Mørkholm 1966, 67; Huß 2001, 514-515, note 1; Mittag 2006, 162-163; Grabbe 2008, 76-77; Grainger 2010, 270.

14 Earlier scholarly views of the chronological problems are summarized by Grabbe 2008, 76-77; see also Kaye - Amitay 2015, 140-141.

15 Bagnall $(1976,21)$ felt that Josephus' account provided valuable information about the organization of tax farming, despite its fanciful aspects. The Tobiad romance was treated as a Jewish legend by Gruen (1997, 83-84), but was defended by Schwartz 1998 and more recently by Sartre 2014, who however seems to reject certain details. Kaye - Amitay 2015 defended Josephus' report of the dowry and tax sharing but argued that it should be divorced from the Tales of the Tobiads.

16 Jos. $A J 12.155$.

17 Jos. $A J 12.156-168$.

18 On the variant manuscripts, see Schwartz 1998, 53-55. Schwartz defended a second-century date for Joseph son of Tobias, and a second-century date is also accepted by Honigman 2014, 342; Sartre 2014, 10; Monson 2016, 21. A second-century date is rejected by Momigliano 1975, 178-180; Bagnall 1976, 21 with note 42; Fuks 2001; Grabbe 2008, 77; Grabbe 2011, 78; Pfeiffer 2011, 202-212.

19 See in particular the comments of Kaye - Amitay 2015, 138-139.

20 Jos. AJ 12.169. 
sureties after charming the adolescent king with an impertinent joke. ${ }^{21}$ Josephus states that the son of Tobias collected these taxes for twenty-two years, and that his farming of the taxes became the basis of a great fortune which he used to lift the Judahites out of poverty. ${ }^{22}$ These circumstances probably fostered the growth of pro-Lagid sentiments in Judah, while the exclusion of tax farmers from the cities of Syria and Phoenicia will have attenuated or ruptured ties between the gentile elites and the Ptolemaic kingdom.

The first annual tax payment to Egypt, so Josephus informs us, was 16.000 talents. $^{23}$ It is natural to suspect that this figure is exaggerated, because Hieronymus reports that the entire Egyptian revenue of Ptolemy II amounted to 14.800 talents in coin per year, and his revenues from Syria and Phoenicia amounted to 8.000 talents per year. ${ }^{24}$ The bid of the competitors of Joseph son of Tobias, 8.000 talents, conforms precisely to the figure given by Hieronymus and was considered "not so far from the truth" by Michael Rostovtzeff. ${ }^{25}$ Joseph's bid of 16.000 talents was obviously intended to be preemptive and was probably unrealistically high.

Ptolemaic tax farmers had some discretion in the assessment of taxes in order to ensure their profits. Josephus describes how Joseph son of Tobias, anticipating resistance from the cities, collected the first year's taxes accompanied by a contingent of 2.000 infantry provided by Ptolemy $\mathrm{V} .{ }^{26}$ The citizens of Ascalon refused to pay and he executed about twenty leading citizens, confiscated all their possessions, and sent them to the Ptolemaic king. ${ }^{27}$ This frightened most of the other cities into compliance, but the men of Scythopolis attempted to resist and suffered the same punishment as those of Ascalon. ${ }^{28}$ It is clear that Joseph's methods of tax collection were abusive, and it is also clear that he targeted gentile cities: besides Ascalon and Scythopolis, the tax payers are described as Syrian cities which opened their gates to him. We see here, perhaps, the roots of the enmity between the gentiles and the Judahites that is such a prominent feature of the early hostilities of the Maccabean revolt as described in First Maccabees. We should also not lose sight of the enormous anomaly that a Ptolemaic agent was allowed to operate at the head of a small Ptolemaic army within Seleucid territory. Unfortunately we do not know whether this was an exceptional situation in the first year of the tax-sharing arrangement, or if it became standard operating procedure.

21 Jos. AJ 12.172-179. On the joke, see Kaye - Amitay 2015, 137-138. The joke should be considered primarily in light the immaturity of Ptolemy V and Cleopatra I, who were sixteen and ten years old, respectively, at the time of their marriage.

22 Jos. AJ 12.186 and 12.224, with 12.186 on the wealth of Joseph son of Tobias. The large money bribes offered to Antiochus IV by Jason and Menelaus for the high priesthood may also reflect the affluence of Judah at this time, see 2 Macc. 4.8-9, 4.24.

23 Jos. $A J$ 12.175-176.

24 Hier. In Dan. 11.5.

25 Rostovtzeff 1941, 1152. On the other hand, Austin $(2006,488)$ and Grabbe $(2011,78)$ both dismissed the figure as impossibly high, and C. Fischer-Bovet also finds it incredible (personal communication).

26 Jos. AJ 12.180. Gera (1998, 57-58) objected that Egyptian tax farmers did not collect taxes, but Grabbe (2011, 78-79) rebutted his criticism, noting that the model was different outside of Egypt. C. FischerBovet (personal communication) suggests the army that backed Joseph son of Tobias might be an exaggeration by Josephus of the usual contingent of machimoi (guards) that accompanied tax farmers in Egypt when they performed their duties.

27 Jos. $A J 12.181$.

28 Jos. $A J 12.182-183$. 
Because the taxes collected by Joseph son of Tobias were levied on cities, we can assume that they were money taxes, not taxes in kind, and they must have been paid in the only high-value currency available, and the only currency that the Ptolemaic king would have accepted-Ptolemaic silver coinage. Twenty-two years of remitting these taxes to Alexandria should have had an impact on the currency supply. Let us provisionally accept the figure of 16.000 talents as a basis for estimating the outflow of silver from Coele Syria and Phoenicia to Egypt. The talent was equivalent to 6.000 drachms, so 16.000 talents was equivalent to 96 million drachms or 24 million tetradrachms. If this rate held for all 22 years, Joseph son of Tobias sent a mind-boggling 528 million tetradrachms to Alexandria. However the sum of 16.000 talents was exceptional, a coup to ensure that Joseph son of Tobias would win his first contract, and his subsequent bids were probably lower to ensure maximum profit for the tax-farming enterprise. Josephus mentions an amount of not less than 3.000 talents (4.500.000 tetradrachms) in the tax account for the year 186 BCE.$^{29}$ Even at lower levels of taxation, the export of millions of tetradrachms per year could have diminished the supply of Ptolemaic silver in Coele Syria and Phoenicia. Indeed, Josephus reports a joke at the Alexandrian court, also in $186 \mathrm{BCE}$, that Joseph son of Tobias had made Syria as bare as a pile of bones. ${ }^{30}$

Here we may raise questions about the larger vision of Antiochus III. He must have foreseen that his tax-sharing policy would result in the export of a substantial quantity of Ptolemaic silver from Coele Syria and Phoenicia. Was it an actual goal of his policy to cleanse the province of Ptolemaic silver and thereby reduce the symbols of Ptolemaic rule? Or did he encourage replenishment of the silver currency through trade with Egypt and Cyprus? ${ }^{31}$ The standard view of numismatists is that ancient states were not concerned with currency supply. ${ }^{32}$ But that view pertains to the minting of new coinage, not to encouragement of international trade. The literary sources provide no clues about the monetary and economic policies of Antiochus III, and ultimately we shall seek answers by examining numismatic data.

Sylvie Honigman has argued that Seleucus IV tried to abrogate the tax-sharing agreement and seize the revenues for himself, either after the death of Ptolemy V in $180 \mathrm{BCE}$ or after the death of Cleopatra I a few years later, and that this change of policy was responsible for rising tensions with the Ptolemaic court and for renewed ambitions in Alexandria to recover the "lost province." 33 Specifically, the alleged attempt of Heliodoros, the king's epi ton pragmaton, to confiscate funds from the Jerusalem temple that had been deposited for safekeeping by Hyrcanus son of Tobias is represented as an attempt to seize tax revenues intended for Ptolemy VI. ${ }^{34}$

The attitude of Antiochus IV toward tax-sharing was definitive. In diplomatic negotiations following his initial invasion of Egypt, he explicitly denied that his father had

29 Jos. $A J 12.200$.

30 Jos. $A J 12.212$.

31 Rostovtzeff $(1941,868)$ and Seyrig $(1973,121)$ assumed strong commercial links between Alexandria and the port cities of Phoenicia in the second century, but they referred specifically to the second half of the century.

32 For a recent statement of this position, see Meadows 2014, 179-181.

33 Honigman 2014, 343; see also Sartre 2014, 11.

342 Macc. 3.4-14; Honigman 2014, 342-344, 378. 
granted Coele Syria and Phoenicia as a dowry to Cleopatra I. ${ }^{35}$ Polybius states that the king convinced himself, as well as the diplomats, of the justice of his position, which implies that the dowry of Cleopatra I was indeed an historical reality. The public repudiation of the dowry by Antiochus IV follows soon after the end of Tobiad tax farming. Assuming that Joseph son of Tobias won the first contract shortly after the marriage of Ptolemy $\mathrm{V}$ and Cleopatra in winter of 194/193 BCE, for the fiscal year 193/192 BCE, the last of his 22 years of tax farming would have been 172/171 BCE, shortly before the outbreak of the Sixth Syrian War. It is highly likely that Antiochus IV terminated the tax-sharing agreement in $171 \mathrm{BCE}$. This would be the casus belli he desired to manufacture around 171, according to Livy 42.29.5, and apparently it provoked the disastrous attempt of Eulaeus and Lenaeus to invade Palestine, which triggered the counterinvasion of Egypt by Antiochus IV. ${ }^{36}$ The termination of the tax-sharing agreement was also a blow to the economic interests of the Tobiad family and probably contrary to the interests of Judah generally, since the Judahites had benefited from the generosity of Joseph son of Tobias. We have to wonder if this was a contributing cause of the Maccabean revolt.

The unhappiness of Seleucus IV with tax-sharing and its ultimate rejection by Antiochus IV do not allow us to infer their attitudes toward the import of fresh Ptolemaic silver and as in the case of Antiochus III we must seek clues in numismatic data.

If new Ptolemaic silver entered Coele Syria and Phoenicia through trade and travel, the main points of entry would be the great coastal emporia and we could expect finds concentrated in Lebanon and near the Palestinian coast. ${ }^{37}$ There is weak support for this position from archaeological excavations in Israel. Twelve second-century Ptolemaic silver coins in the collection of the Israel Antiquities Authority have secure excavation provenances, but only two are from the coast: one coin is from the old city of Akko and another from Ashdod, while ten are from El'ad (Mazor), a site in the foothills of Samaria, on the border of the Shephelah, whose central farmstead was occupied by wealthy, Hellenized inhabitants who consumed foreign imports such as Rhodian wine. ${ }^{38}$ The coin from Akko is a Paphian tetradrachm of the eighteenth regnal year of Ptolemy VI, equivalent to 164/163 BCE. ${ }^{39}$ The coin from Ashdod is a didrachm "of an uncertain era" dated year 109, equivalent to $154 / 153 \mathrm{BCE} .^{40}$ The ten coins from El'ad (Mazor) comprised two small hoards and one coin found in isolation. ${ }^{41}$ Three undated Alexandrian tetradrachms

35 Polyb. 28.20.9.

36 Diod. 30.16. The disputes about Coele Syria which Antiochus IV sought to raise around 171 were previously connected with the tax-sharing arrangement by Schwartz 1998, 49-50.

37 Numismatists have debated whether new Ptolemaic coinage entered Coele Syria through trade and travel, or through military operations, with military operations favored by Hazzard 1975; Lorber 2007. Barag (2007/2008, 37) cited lack of evidence for special economic ties between Ptolemaic Cyprus and Seleucid Coele Syria and Phoenicia and suggested that the Ptolemaic mints on Cyprus profited by exchanging fresh coins for worn ones at a commission. No evidence supports this intriguing hypothesis.

38 I am grateful to Donald Tzvi Ariel for researching these coins for me in September of 2017, and for informing me of subsequent finds. The finds from $\mathrm{El}^{\text {' }} \mathrm{ad}$ are to be published by Ariel in an excavation report.

39 IAA 106364 (Svoronos 1908, IV: Addenda 1430A).

40 IAA 10707 (Svoronos 1904, II: no. 1216).

41 In the following notes, coins with IAA inventory numbers were found at El'ad Site A2, the central farmstead, and represent one of the two small hoards. The second hoard was composed of the coins with registry numbers, which were found at Site D32(A8), a satellite farmstead, at Locus 54 in Room C near the northern wall. The closing dates of the two hoards, 166/165 BCE for the first and c. 170?-c. 155? BCE for 
from the early years of Ptolemy V (Svoronos 1231) may have entered Ptolemaic Syria and Phoenicia during the Fifth Syrian War. ${ }^{42}$ Four of the El'ad coins belong to a massive issue of undated Alexandrian tetradrachms of Ptolemy VI (Svoronos 1489) whose production began in or shortly before $174 \mathrm{BCE}$ and was probably particularly intense before the outbreak of the Sixth Syrian War, but may have lasted as late as 155 BCE. ${ }^{43}$ The three other El'ad coins date from the $160 \mathrm{~s} \mathrm{BCE} .{ }^{44}$ Of the twelve provenanced coins in the Israel National Collection, nine entered the province no earlier than the reign of Antiochus IV, and five of them arrived after the Sixth Syrian War. The archaeological record thus fails to document the arrival of fresh Ptolemaic silver during the reigns of Antiochus III and Seleucus IV, or indeed during the entire twenty-two-years of the taxsharing agreement. The ten unprovenanced coins in the Israel National Collection show a similar pattern: the earliest issues struck after the Seleucid conquest of Coele Syria and Phoenicia are two Ptolemaic tetradrachms "of an uncertain era" from Cyprus, dated to era years 89 and 90, equivalent to $174 / 173$ and 173/172 BCE. ${ }^{45}$ Six other Ptolemaic coins belong to the enormous, undated Alexandrian issue that commenced around 174 BCE and continued until an uncertain date (Svoronos 1489-1490), while two are later. ${ }^{46}$ It goes without saying that the dates of issue of these coins are not necessarily the dates at which they entered Coele Syria and Phoenicia, but only termini post quem. The sample from the Israel National Collection, though not impressively large, is consistent and suggests provisional hypotheses that can be tested against future discoveries: Antiochus III intended his tax-sharing agreement with Ptolemy V to drain Lagid silver from Coele Syria and Phoenicia. The entry of new Ptolemaic silver issues into the province was prohibited, perhaps by Antiochus, perhaps by Ptolemy V, or perhaps by mutual agreement. The ban continued under Seleucus IV but ended under Antiochus IV, possibly only after the Sixth Syrian War. It is not clear whether the change in policy was ordered by Antiochus himself or by the Ptolemaic state, but mutual agreement seems unlikely at this period. The preponderance of Alexandrian issues of the type Svoronos 1489 in the Israel National Collection could perhaps reflect booty captured by Antiochus IV during the war, though more likely any captured coins were reminted on the Attic standard at

the second, are both earlier than the destruction of the site, which is dated c. $145 \mathrm{BCE}$ by stamped amphora handles.

42 IAA 49053 and registry no. 0033-3 (Svoronos 1904, II: no. 1231), as well as another example found in isolation. That these coins could have entered the province together with the next group is suggested by the Tanis hoard of 1986 (EH I, 208) which included two examples of Svoronos 1231 along with 461 examples of Svoronos 1489, see Faucher - Olivier - Brissaud - Desbordes 2017.

43 IAA 49003 and registry nos. 0033-1, 0033-2, and 0033-4 (Svoronos 1904, II: no. 1489). On the chronology of this issue, see Carlen - Lorber 2018, 24-26.

44 IAA 49025 (Mørkholm - Kromann 1984, no. 47), a tetradrachm of Citium dated to the second regnal year of the joint reign of Ptolemy VI and VIII, equivalent to 169/168 BCE; IAA 49024 and IAA 49034 (both Svoronos 1904, II: no. 1311), tetradrachms of Paphos dated to the fifth year of the joint reign of Ptolemy VI and VIII, equivalent to 166/165 BCE.

45 Svoronos 1904, II: nos. 1111 and 1112 (IAA 51724 and 51725, both from the British Mandate Collection). On the Ptolemaic era coinage and the attribution of its second series to Cyprus, see Olivier 2018, 36-39.

46 Struck in or after c. 174: Svoronos 1904, I: nos. 1489 (IAA 2410, 46736, 51731, 140064) and 1490 (IAA 51733, 51734). In addition there is an era didrachm of year 101, equivalent to 162/161 BCE (Svoronos 1904, II: no. 1209, IA 51738) and a Salaminian tetradrachm of regnal year 31, equivalent to 151/150 BCE (Svoronos 1904, II: no. 1445, IAA 51732). 
Antioch and perhaps also Ptolemais-Akko, both of which markedly intensified their production of silver coinage after the Egyptian invasions. ${ }^{47}$

The coin hoards of El'ad can be supplemented by other hoards, but these provide only a sketchy picture of how the supply of Ptolemaic silver changed over the reigns of Antiochus III and his sons. There is a twenty-five-year gap in the record of coin hoards that corresponds roughly to the duration of the tax-sharing arrangement. No silver hoards were deposited in the closed monetary zone between 198 BCE, the year of the final Seleucid conquest, and the late $170 \mathrm{~s} \mathrm{BCE} .^{48}$

There are three silver hoards from the end of the 170s BCE: one said to be from Jordan, with a closing date of 174/173 BCE; ${ }^{49}$ a second from Jordan with a closing date of $172 / 171 \mathrm{BCE} ;{ }^{50}$ and a third from the Jericho area, recorded around 1991 by the late Arnold Spaer ( $C H$ VIII, $412=E H$ I, 111), with a closing date of 171/170 BCE. ${ }^{51}$ Only the first and third hoards are well documented. Both contained Ptolemaic coinage exclusively, including recent issues of Ptolemy V and VI, with Ptolemaic era tetradrachms from Cyprus predominant. Together these two hoards account for many more coins than those known from excavations, 290+ in the case of the Jordan hoard, 46+ in the case of the hoard from the Jericho area. Remarkably, these hoards suggest that new Ptolemaic coins were being introduced from the east, or at least they were accumulating along the eastern border of Judah.

The Jordanian hoard closing in 174/173 BCE is the third largest silver hoard known from Hellenistic Syro-Phoenicia. Elsewhere I have ventured to suggest that its loss might be associated with the death of Hyrcanus, youngest son of Joseph son of Tobias. ${ }^{52}$ Throughout the reign of Seleucus IV Hyrcanus had resided in the ancestral Tobiad estates in Ammanitis, where he constructed a luxurious, fortified palace. ${ }^{53}$ According to Josephus Hyrcanus died by his own hand early in the reign of Antiochus IV, because the king was approaching with an army and Hyrcanus feared punishment for warring with

47 Mørkholm 1963, 35-37, 51. Moreover, the treatment of bronze coinage from Ptolemaic Cyprus during and after the Seleucid occupation of Cyprus in 168 suggests that Antiochus was hostile to Ptolemaic coinage. Although Cypriote bronze coins of Ptolemy VI were apparently taken to Syria as booty, they were countermarked with a Seleucid anchor, see Lorber 2001, 47-48. Larger denominations left behind on Cyprus were defaced by erasing the name Ptolemy from the coins.

48 For the three hoards deposited in 198, see Lorber, forthcoming a: Syria, 1981 ( $C H$ VII, $90=C H$ VIII, $339=E H$ I, 105): Meadows 2017a, 187-188; Balatah, 1960 (IGCH $1588=E H$ I, 108): Carlen 2014, 52, 57 and Madaba, c. 1919 (IGCH 1592 =EH I, 112). The closure of the Madaba hoard has been muddied. Jenkins (1967, 69 note 26) reported that the latest coin was of Ptolemy V, presumably based on autopsy of the hoard coins kept in the British Museum. However the entry in IGCH cites Newell's identification of an undated tetradrachm of Ptolemy VI (Svoronos 1489). Inexplicably, U. Westermark assigned a burial date after 146 BCE and this was followed by Duyrat (2016, 131, no. 216).

49 Recorded in two lots, in 2016 and 2019, from photos supplied by a Middle Eastern dealer.

50 This hoard appeared in Israeli and American commerce in 2013 but was recorded incompletely. The 35 coins recorded were all issues of Ptolemy V and VI, predominantly era tetradrachms from Cyprus.

51 Published from Spaer's notes by Olivier - Meadows 2017. These authors identified another 30 coins in commerce which in their opinion probably came from the same hoard and which lowered the closure date by one year, to $171 / 170 \mathrm{BCE}$.

52 Lorber, forthcoming b. On the career of Hyrcanus and his relations with the Ptolemaic king, see Jos. AJ 12.196-222.

53 Jos. AJ 12.229-234. 
the local Arabs. ${ }^{54}$ Honigman suggests that his suicide was instead related to a dispute over the revenues of Coele Syria and Phoenicia. ${ }^{55}$ Indeed, Josephus states that Hyrcanus compelled the barbarians of the Transjordan to pay their taxes. ${ }^{56}$ This probably means that he was a tax farmer in service to the Ptolemies, very likely a partner (metochos) of his father, responsible for collecting the taxes of outlying districts. ${ }^{57}$ The barbarians so taxed probably included Arabs engaged in the lucrative spice trade. Possibly Hyrcanus used his father's coercive methods, and this might account for his "perpetual war with the Arabs." ${ }^{58}$ Antiochus may have attacked Hyrcanus over taxes, or to protect the spice trade, but strategic concerns were doubtless more compelling. As Sartre emphasizes, Hyrcanus was inevitably viewed as a Ptolemaic agent. ${ }^{59}$ If Antiochus IV was already planning a war with Egypt, he could not leave a friend of the Ptolemaic king with a fortified power base and ample monetary resources in his rear. Nevertheless the Transjordan apparently remained outside Seleucid control, for after c. 171 the deposed high priest Jason took refuge there. ${ }^{60}$ The Jordanian hoard closing in 172/171 also implies that Antiochus' attack on Hyrcanus failed to eradicate the nexus between Ammanitis and the Lagid kingdom.

An interesting aspect of the silver hoards from the end of the 170s is that they are the latest hoards to contain Ptolemaic coinage from the third century BCE. The next generation of silver hoards attests both the disappearance of older Ptolemaic coinage, including the era tetradrachms from Cyprus, and the arrival of fresh Ptolemaic silver struck under Ptolemy VI. The hoards thus complement the material in the Israel National Collection. ${ }^{61}$ Only two published silver hoards were deposited in Coele Syria and Phoenicia in the 160s BCE: The small Southern Palestine hoard of 1977 (CH IV, $58=E H$ I, 115), with a closing date of 164/163, contained only tetradrachms of Ptolemy VI, predominantly of the Alexandria mint and belonging to the undated issue Svoronos 1489 that commenced in c. $174 \mathrm{BCE} .{ }^{62} \mathrm{~A}$ hoard found in the Bethlehem area in 1984 ( $\mathrm{CH}$ VIII, $432=E H \mathrm{I}$, 113) closed in 162/161 and contained 9 tetradrachms of Ptolemy VI from Alexandria and Cyprus, as well as one Ptolemaic didrachm "of an uncertain era." ${ }^{163}$ These hoards, together with the finds from $\mathrm{El}^{\text {'ad }}$ (Mazor), demonstrate that recently minted Ptolemaic

54 Jos. $A J 12.236$.

55 Honigman 2014, 378-379.

56 Jos. AJ 12.222 .

57 Honigman 2014, 342, describes Hyrcanus as successor to his father, but his suicide appears to have preceded the abrogation of the tax-sharing agreement by several years.

58 Jos. $A J 12.229$.

59 Sartre 2014, 8, 10.

602 Macc. 4.26; 5.5-7.

61 The three specimens of Svoronos 1231 found at El'ad (Mazor) represent a partial or qualified exception, as they may have passed as examples of Svoronos 1489.

62 The hoard contained one Paphian tetradrachm of year 7 of the joint reign of Ptolemy VI and VIII (Svoronos 1333), equivalent to 164/3 BCE, and either three or fifteen examples of Svoronos 1489, see Meadows 2017b. Duyrat $(2016,122)$ favored the lower number. Only two coins were photographed, and they are in fresh condition.

63 Published by Meadows 2017c on the basis of Spaer's notes. Carlen 2017 proposed a reconstruction of the hoard that enlarged it to at least 50 and perhaps more than 90 coins and lowered its closing date to 154/3 BCE. The coins added by Carlen were all issues of Ptolemy VI, but several coins are dated well before c. 170 BCE: nos. 22 (179/8), 23 (177/6), 24 (178/7), 52 (176/5), and 59 (177/6). Skepticism is in order be- 
silver was circulating in the closed monetary zone of Coele Syria and Phoenicia, and specifically in Judah, at the time of the Maccabean revolt.

The disappearance of older Ptolemaic silver seems to have occurred rather suddenly around 170 BCE. Third-century coins, especially issues of Ptolemy I and II, constituted a significant proportion of the Jordian hoard closing in 174/173. Era tetradrachms of Cyprus comprised about a quarter of the same hoard and were the dominant component of the other hoards of the late 170s. All these varieties are absent from the hoards of the 160s. We cannot relate their disappearance to the remission of tax payments to Alexandria because the hoards of the late 170 s come from a limited geographical area, leaving us in the dark about developments in Phoenicia and western Palestine.

One possibility that Antiochus IV cancelled the tax-sharing agreement in $171 \mathrm{BCE}$ precisely because the province of Coele Syria and Phoenicia was cleansed of Ptolemaic silver to the degree that it could no longer afford the tax payments. An alternative hypothesis is that the monetary reforms of Antiochus IV may have included an attempt, somewhere around $170 \mathrm{BCE}$, to confiscate the Ptolemaic silver in the province. This may account for the dramatic increase in tetradrachm production at Ptolemais-Akko c. 169/168 BCE. A confiscation could conceivably lie behind Josephus' statement that the king plundered Jerusalem of a great deal of money in the hundred and forty-third year of the Seleucid era (169/168 BCE) ${ }^{64}$

In 169/168, the year of his first alleged attack on Jerusalem, Antiochus IV undertook a currency reform with ethnic implications. He introduced a new type of bronze coinage that blended royal and civic authority: the coins bore the king's portrait, but were issued in the names of nineteen cities from Cilicia to Mesopotamia, including seven in Phoenicia. ${ }^{65}$ This coining privilege has been interpreted mainly in the framework of power relations between the king and the cities. ${ }^{66}$ But the timing is noteworthy and we have to suspect some connection between the currency reform and the ethnic split so evident in the Maccabean revolt: the gentiles, including the Phoenicians of the coast, supported the king and opposed not only the revolt but even the practice of Yahwist cult. Royal armies are involved in only a few of the battles described in First Maccabees; most of the conflict is between the rebels and gentiles.

In this fraught period of the 160s BCE the coinage "of an uncertain era" was revived, with a new specialization in the production of didrachms. Julien Olivier has made a plausible case that the first phase of this didrachm coinage represented a subsidy from Ptolemy VI to the Maccabees, and that it was minted in Judah. ${ }^{67}$ I should like to add further arguments in support of these hypotheses. (1) The earliest hoard provenance for an era didrachm is the Bethlehem area hoard cited above, with a closure date of 162/161 BCE. (2) Second Maccabees 12.43 recounts how, after finding pagan

cause the added coins do not closely match the recorded content of the Bethlehem area hoard, and because the reconstruction so markedly deviates from the patterns established by other evidence.

64 Jos. AJ 12.247. Josephus' source, 1Macc 1.20-23, describes a plundering of the temple only, including cult utensils and hidden treasures.

65 Mørkholm 1965.

66 Mørkholm 1965, 67; Mørkholm 1984, 101; Hoover 2004, 489-490; Capdetrey 2007, 213-214, 220 221; Iossif 2014, 79.

67 Olivier 2018, 41-44. 
amulets on the Judahite dead, Judas Maccabaeus took up a collection among his troops to finance a sin offering and it amounted to 2.000 silver drachms. The implication is that the rebel troops were well supplied with silver currency and carried it with them on campaign. (3) A detail of the revived era coinage seems to reflect Judahite religious sensibilities. In the first two series of era coinage the legend invariably names Ptolemy Soter as the issuing authority, using the cult epithet under which the dynastic founder was worshipped as a god. The third series of era coinage names Ptolemy the King. Judahites avoided the use of Ptolemaic cult epithets, as attested by a series of seven inscriptions from Egypt which dedicate proseuchai (houses of prayer) on behalf of the Ptolemaic king and queen, omitting their cult epithets, whereas the cult epithets are regularly included in c. 120 dedications erected by their Greek or Egyptian subjects. ${ }^{68}$ (4) Didrachms were exceptional in the coinage of Ptolemaic Egypt and had a distinctly limited role on Cyprus. Why, then, did the revived era coinage consist mainly of didrachms, not tetradrachms as formerly? Could it be that the denomination was chosen to match a requirement for temple dues? ${ }^{69}$

The interference of Ptolemy VI in the affairs of Judah may not have been limited to the third series of era coins. As already noted, after $170 \mathrm{BCE}$ the earliest finds of Ptolemaic silver in Seleucid Coele Syria and Phoenicia consist almost exclusively of coins from Alexandria and Cyprus, and they are concentrated in or near Judah. These coins may represent additional monetary subsidies from the Ptolemaic king. A not-altogether-reliable literary source, Second Maccabees 10.20, reports a substantial sum of 70.000 drachms $\left(11^{2 / 3}\right.$ talents) in the hands of Idumaean opponents of the Maccabees, possibly implying that Ptolemy VI did not limit his subsidies to Judahite rebels, and this may also be an implication of the finds at El'ad (Mazor). The finds at Akko and $\mathrm{El}$ 'ad (Mazor) might also be cited to support a claim that trade contributed to the influx of fresh Ptolemaic coinage, but the case is very weak.

The monopoly of Ptolemaic silver in Coele Syria and Phoenicia was broken by the Seleucid "eagles," silver coins issued in the names of the reigning Seleucid king and bearing his portrait, but conforming to the Lagid weight standard and employing the familiar Lagid eagle reverse type. Seleucid "eagles" were introduced tentatively and on a very limited scale by Antiochus $V,{ }^{70}$ probably in direct response to the revival of the Ptolemaic era coinage and to the new influx of Ptolemaic tetradrachms from Cyprus and Egypt. Regular production of the Seleucid "eagles" was instituted by the usurper Alexander Balas, a protégé of Ptolemy VI. In 151/150 BCE Balas began an annual production of "eagles" at four Phoenician mints, with the tetradrachm as the standard denomination. ${ }^{71}$ The production of the "eagles" was on a much larger scale than that of the era didrachms, which in any case was winding down in Judah. Olivier estimated the

68 OGIS 726; IFay 1.1; OGIS 96; OGIS 101; IDelt 525.1; OGIS 742; IAlex 62. An eighth dedication of a proseuche, IDelt 960.1, uses the epithet Euergetai (Benefactors) but without Theoi (Gods), so that the implication of ruler worship is avoided.

69 A temple tax of half a shekel, equivalent to 2 drachms, is attested in Exod. 30: 13-15; 38: 26, however the amount is a third of a shekel in Neh. 10: 32. The allusion to temple dues is not meant to imply that the era didrachms were struck for the temple, but only that the didrachm denomination may have been favored by Judahite soldiers.

70 Houghton - Lorber - Hoover 2008, no. 1583.

71 Houghton - Lorber - Hoover 2008, nos. 1824, 1830-1832, 1835-1837, 1842. 
output of era didrachms from 162/161 to $152 / 151$ BCE at 150 to 200 talents. $^{72}$ The output of Seleucid "eagles" during Balas' reign can be estimated at 400 talents for Berytus, 200 talents for Sidon, 692 talents for Tyre, and 400 talents for Ptolemais, for a total of 1,692 talents. $^{73}$

In 147 BCE Ptolemy VI occupied the coastal cities of Palestine and Phoenicia. A small change in the metallic composition of the era didrachms, and a larger change in the distribution of their findspots, led Julien Olivier to suggest that the mint had moved from Judah to a coastal site and that the coinage now supported the invasion of Ptolemy Philometor and his march on Syria. ${ }^{74}$ Production of the era didrachms ended in the year of Philometor's death, 146/145 BCE. His successor, Ptolemy Euergetes II, did not renew an alliance with the Maccabees, and Ptolemaic silver apparently played no further role in the emergence of a Hasmonean state.

Conclusions. Ptolemaic silver did not enter the closed monetary zone of Seleucid Coele Syria and Phoenicia through the port cities of Phoenicia, but rather accumulated in the Transjordan and eastern Judah. The specific goals of Antiochus III and his sons with respect to Ptolemaic silver remain elusive. On the other hand, coin finds demonstrate a strong linkage between Ptolemaic silver and Judahites, with finds first concentrated in the Transjordan, the ancestral territory of the Tobiad family, and later in Judah itself. In this sense the numismatic evidence tends to support Josephus' account of Tobiad tax farming, while inspiring modern suspicions that Ptolemaic silver was a tool for undermining Seleucid rule in Coele Syria and Phoenicia and, specifically, for encouraging rebellion in Judah. However Ptolemy VI probably did not limit his subsidies to Judahites; most likely he also sought to sow disaffection with Seleucid rule in gentile communities.

ABbreviations

CH - Coin Hoards. Periodical publication of the Royal Numismatic Society, 1973-2002, and of the

American Numismatic Society and Royal Numismatic Society, 2010.

EH I - T. Faucher, A. Meadows, C. Lorber (eds.). (2017), Egyptian Hoards I: The Ptolemies, Cairo.

IGCH - M. Thompson, O. Mørkholm, C. M. Kraay (eds.) (1973), An Inventory of Greek Coins Hoards,

New York.

72 Olivier 2018, 43.

73 These calculations are based on statistical estimates of the original number of dies as reported by Sawaya 2005, 106; Iossif 2011, 214, 215, and on the assumption of an average output of 20.000 tetradrachms or $13 \frac{1}{3}$ talents per obverse die. The estimated output for Ptolemais is based on the estimate of Voulgaridis (2000) that the mint employed an average of 5 obverse dies annually under Alexander I.

74 Olivier 2018, 49-51. 
Austin, M. M. (2006), The Hellenistic World from Alexander to the Roman Conquest: A Selection of Ancient Sources in Translation, $2^{\text {nd }}$ ed., Cambridge.

Bagnall, R. S. (1976), The Administration of the Ptolemaic Possessions Outside Egypt, (Columbia Studies in the Classical Tradition IV), Leiden.

Barag, D. (2007/2008), Ptolemaic Silver Currency of Cyprus in Seleucid Phoenicia and Coele-Syria, Israel Numismatic Journal 16: 28-56.

Capdetrey, L. (2007), Le pouvoir séleucide : Territoire, administration, finances d'un royaume hellénistique (312-129 av. J.-C.), Rennes.

Carlen, E. A. (2014), A Review of the Shechem Hoard, Israel Numismatic Research 9: 39-59.

Carlen, E. A. (2017), The Larger Context of the 1984 Bethlehem Area Hoard (CH VIII, 432), Israel Numismatic Research 12: 47-63.

Carlen, E. A., Lorber, C. C. (2018), Silver Coinage from the Co-regency of Ptolemy VI and VIII, Israel Numismatic Research 13: 3-33.

Duyrat, F. (2016), Wealth and Warfare: The Archaeology of Money in Ancient Syria, New York.

Faucher, T., Olivier, J., Brissaud, P., Desbordes, C. (2017), EH 208. Trésor de Tanis, 1986), in: T. Faucher, A. Meadows, C. Lorber (eds.), Egyptian Hoards I: The Ptolemies, Cairo: 203-222 and pl. 59-89.

Fuks, G. (2001), Josephus' Tobiads Again: A Cautionary Note, Journal of Jewish Studies 52: 354-356.

Gera, D. (1990), On the Credibility of the History of the Tobiads (Josephus Antiquities 12, 156-122, 228-236), in: A. Kasher et al. (eds.), Greece and Rome in Eretz Israel: Collected Essays, Jerusalem: 21-38.

Gera, D. (1998), Judaea and Mediterranean Politics 219 to 161 B.C.E., (Brill's Series in Jewish Studies 8), Leiden.

Grabbe, L. L. (2008), A History of the Jews and Judaism in the Second Temple Period, vol. 2: The Coming of the Greeks: The Early Hellenistic Period (335-175 BCE), (Library of Second Temple Studies 68), London-New York.

Grabbe, L. L. (2011), Hyparchs, Oikonomoi and Mafiosi: The Governance of Judah in the Ptolemaic Period, in: L. L. Grabbe, O. Lipschitz (eds.), Judah between East and West: The Transition from Persian to Greek Rule (ca. 400-200 BCE), New York: 70-90.

Grainger, J. D. (2010), The Syrian Wars, (Mnemosyne Supplement 230), Leiden-Boston.

Gruen, E. (1997), Fact and Fiction: Jewish Legends in a Hellenistic Context, in: P. Cartledge, P. Garnsey, E. Gruen (eds.), Hellenistic Constructs: Essays in Culture, History, and Historiography, Berkeley: $72-88$.

Hazzard, R. A. (1975), The Tyre Hoard of 1955: IGCH 1551, Cornucopiae 3: 57-63.

Honigman, S. (2014), Tales of High Priests and Taxes: The Book of the Maccabees and the Judean Rebellion against Antiochus IV, (Hellenistic Culture and Society 56), Oakland, CA.

Hoover, O. (2004), Ceci n'est pas l'autonomie: The Coinage of Seleucid Phoenicia as Royal and Civic Power Discourse, Topoi Supplement 6: 485-507.

Houghton, A., Lorber, C. (2000/2002), Antiochus III in Coele-Syria and Phoenicia, in: D. Barag (ed.), Studies in Memory of Leo Mildenberg, Israel Numismatic Journal 14: 44-58.

Houghton, A., Lorber, C., Hoover, O. (2008), Seleucid Coins: A Comprehensive Catalogue, part II: Seleucus IV through Antiochus XIII, New York-Lancaster-London.

Huß, W. (2001), Ägypten in hellenistischer Zeit 332-30 v.Chr., Munich.

Iossif, P. (2011), Seleucid 'Eagles' from Tyre and Sidon: Preliminary Results of a Die-Study, in: N. Holmes (ed.), Proceedings of the XIV th International Numismatic Congress, Glasgow 2009, Glasgow: 213-229.

Iossif, P. (2014), The Last Seleucids in Phoenicia: Juggling between Civic and Royal Identity, American Journal of Numismatics 26: 61-87. 
Jenkins, G. K. (1967), The Monetary Systems in the Early Hellenistic Time with Special Regard to the Economic Policy of the Ptolamaic Kings, in: A. Kindler (ed.), International Numismatic Convention, Jerusalem 27-31 December 1963, The Pablerns of Monetary Development in Phoenicia and Palestine in Antiquity, Tel-Aviv - Jerusalem: 53-74.

Kaye, N., Amitay, O. (2015), Kleopatra's Dowry: Taxation and Sovereignty between Hellenistic Kingdoms, Historia 64: 131-155.

Le Rider, G. (1975), Contremarques et surfrappes dans l'Antiquité greque, in: J.-M. Dentzer, P. Gauthier, T. Hackens (eds.), Numismatique antique : Problèmes et méthodes. Actes du colloque organisé à Nancy du 27 septembre au 2 octobre 1971 par l'Université de Nancy II et l'Université Catholique de Louvain, (Annales de l'Est Mémoire 44), Nancy-Louvain: 27-56.

Le Rider, G. (1995), La politique monétaire des Séleucides en Coelé Syrie et en Phénicie après 200. (Réflexions sur les monnaies d'argent lagides et sur les monnaies d'argent séleucides à l'aigle), BCH 119: 391-404.

Lorber, C. C. (2001), The Lotus of Aphrodite on Ptolemaic Bronzes, SNR 80: 39-52.

Lorber, C. C. (2007), The Ptolemaic Era Coinage Revisited, NC 167: 105-117.

Lorber, C. C. (forthcoming a), Numismatic Evidence for the Chronology of the Fifth Syrian War, in: S. Honigman, O. Lipschits, C. Nihan, T. Römer (eds.), Times of Transition: Judaea in the Early Hellenistic Period, Tel Aviv.

Lorber, C. C. (forthcoming b), Silver Coinage in Seleucid Coele Syria and Phoenicia: Implications for the History of Judah, in: P. Kosmin, A Berlin (eds.), The Middle Maccabees.

Meadows, A. (2014), The Spread of Coins in the Hellenistic World, in: P. Bernholz, R. Vaubel (eds.), Exploring Monetary and Financial Innovation, (Financial and Monetary Policy Studies 39), Berlin-New York: 169-194.

Meadows, A. R. (2017a), EH 105. The "Syria" 1981 Hoard (CH 7.90, 8.306, 8.311, 8.332, 8.433), in: T. Faucher, A. Meadows, C. Lorber (eds.), Egyptian Hoards I: The Ptolemies, Cairo: 150-194 and pl. 48-58.

Meadows, A. R. (2017b), EH 115. Southern Palestine, 1977 (CH 4.58), in: T. Faucher, A. Meadows, C. Lorber (eds.), Egyptian Hoards I: The Ptolemies, Cairo: 223 and pl. 90.

Meadows, A. R. (2017c), EH 113. The Bethlehem Area Hoard, 1984 ( $C H$ 8.432), in: T. Faucher, A. Meadows, C. Lorber (eds.), Egyptian Hoards I: The Ptolemies, Cairo: 224.

Mittag, P. F. (2006), Antiochos IV. Epiphanes, (Klio Beiheft N.S. 11), Berlin.

Momigliano, A. (1975), I Tobiadi nella preistoria del moto maccabaico, in: A. Momigliano, Quinto contributo alla storia degli studi classici e del mondo antico, Rome: 597-628 (Reprint of 1931/1932 original).

Monson, A. (2016), The Jewish High Priesthood for Sale: Farming out Temples in the Hellenistic Near East, Journal of Jewish Studies 67: 15-35.

Mørkholm, O. (1963), Studies in the Coinage of Antiochus IV of Syria, Copenhagen.

Mørkholm, O. (1965), The Municipal Coinages with Portrait of Antochus IV, Congresso internazionale di Numismatica, Roma 1961, Atti, Rome: 63-67.

Mørkholm, O. (1966), Antiochus IV of Syria, Gyldendal.

Mørkholm, O. (1984), The Monetary System in the Seleucid Empire after 187 B.C., in: W. Heckel, R. Sullivan (eds.), Ancient Coins of the Graeco-Roman World: The Nickle Numismatic Papers, Waterloo: 93-113.

Mørkholm, O., Kromann, A. (1984), The Ptolemaic Silver Coinage on Cyprus, 192/1-164/3 B.C., Chiron 14: 149-165.

Olivier, J. (2018), Coinage as a Tool of Ptolemy VI Philometor's Policies: Ptolemaic Coins in Coele Syria and Phoenicia in the Middle of the Second Century BCE, Israel Numismatic Research 13: 35-54.

Olivier, J., Meadows, A. R. (2017), EH I 111. Jericho Area, c. 1991 (CH 8.412), in: T. Faucher, A. Meadows, C. Lorber (eds.), Egyptian Hoards I: The Ptolemies, Cairo: 197-202.

Pfeiffer, S. (2011), Die Familie des Tubias: Eine (trans-)lokale Elite in Transjordanien, in: B. Dreyer, P. F. Mittag (eds.), Lokale Eliten und hellenistische Könige: Zwischen Kooperation und Konfrontation, (Oikumene 8), Berlin: 191-215. 
Rostovtzeff, M. (1941), Social and Economic History of the Hellenistic World, 3 vols., Oxford.

Sartre, M. (2014), Histoire et mémoire(s) des Maccabée, in: M.-F. Baslez, O. Munnich (eds.), La mémoire des persécutions: Autour des livres des Maccabées, Paris-Louvain-Walpole, MA: 1-20.

Sawaya, Z. (2005), Les tétradrachmes séleucides à l'aigle de Bérytos, NC 165: 99-124.

Seyrig, H. (1973), Trésors du Levant anciens et nouveaux, (Trésors monétaires séleucides II, Bibliothèque archéologque et historique 94), Paris.

Schwartz, D. R. (1998), Josephus' Tobiads: Back to the Second Century?, in: M. Goodman (ed.), Jews in a Graeco-Roman World, Oxford: 47-61.

Svoronos, J. N. (1904), Ta Nomismata tou Kratous ton Ptolemaion, 3 vols., Athens.

Svoronos, T. N. (1908), Die Münzen der Ptolemaeer, IV. Band, Deutsche Übersetzung des I. Bandes, Beiträge von F. Huttsch, K. Regling etc., Athons.

Voulgaridis, G. (2000), Les ateliers monétaires de Ptolémaïs- 'Akko et d'Ascalon sous la domination séleucide, unpublished Ph.D. diss., Université Marc Bloch, Strasbourg. 